Beringians of Demuth's narrative, in contrast to "foreigners" who come and go with the economic tides.

In Beringia, snow and ice melt late in summer. Its waters are among the most nutrient-rich in the world, building the basis for food chains that include large populations of "floating" megafauna, such as walruses and 100-tonne whales. That richness ultimately made human communities viable. Demuth follows human and animal trails across vast geographies and in archives from Fairbanks, Alaska, to Vladivostok in Russia.

\section{SHIFTING LANDSCAPE}

Her narrative starts at sea in 1848 , with fleets from New England sparking industrial whaling, their harvests soon vastly exceeding local ones but fluctuating year on year. She moves on to the "floating coast", the zone of constant friction between sea ice and shoreline, where Arctic foxes and walruses thrive. Yet the phrase has a double meaning: this mix of land and ocean is also an "incorporeal social realm". Generations past, Indigenous spiritual practices included shape-shifting rituals in which shamans and hunters moved in and out of incarnations as whales, walruses or polar bears.

Continuing inland, Demuth examines exploration and enterprise. Caribou herding, introduced to Indigenous people in the US territory of Alaska in the late nineteenth century, was favoured both there and in the Soviet Union as a tool for increasing economic output. It went through cycles of boom and bust, and state encouragement of the practice was abandoned only after the Second World War. Gold panning started with the 1898 gold rush in Nome, Alaska. Both the United States and Siberia were interested in Beringia's tin deposits: between the world wars, the strategic metal was used in aeroplanes, tools, ball bearings and the food tins increasingly necessary in rapidly urbanizing societies.

Mining seemed to offer a more predictable source of wealth. But external markets fluctuated, and on-the-ground realities were both inhumane and unworkable. Soviet mines, for instance, operated as part of the Gulag forcedlabour-camp system, at tremendous cost of human lives. Subterranean Beringia turned out to be as unpredictable as its coast.

Returning, finally, to the sea, Demuth follows postwar Soviet attempts to reignite whaling to reach government targets. After violating international quotas, that too ceased, in 1979.

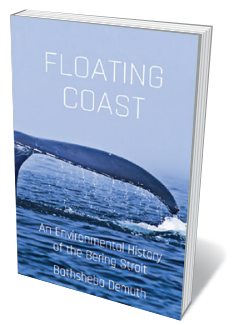

Floating Coast: An Environmental History of the Bering Strait BATHSHEBA DEMUTH

Floating Coast is an

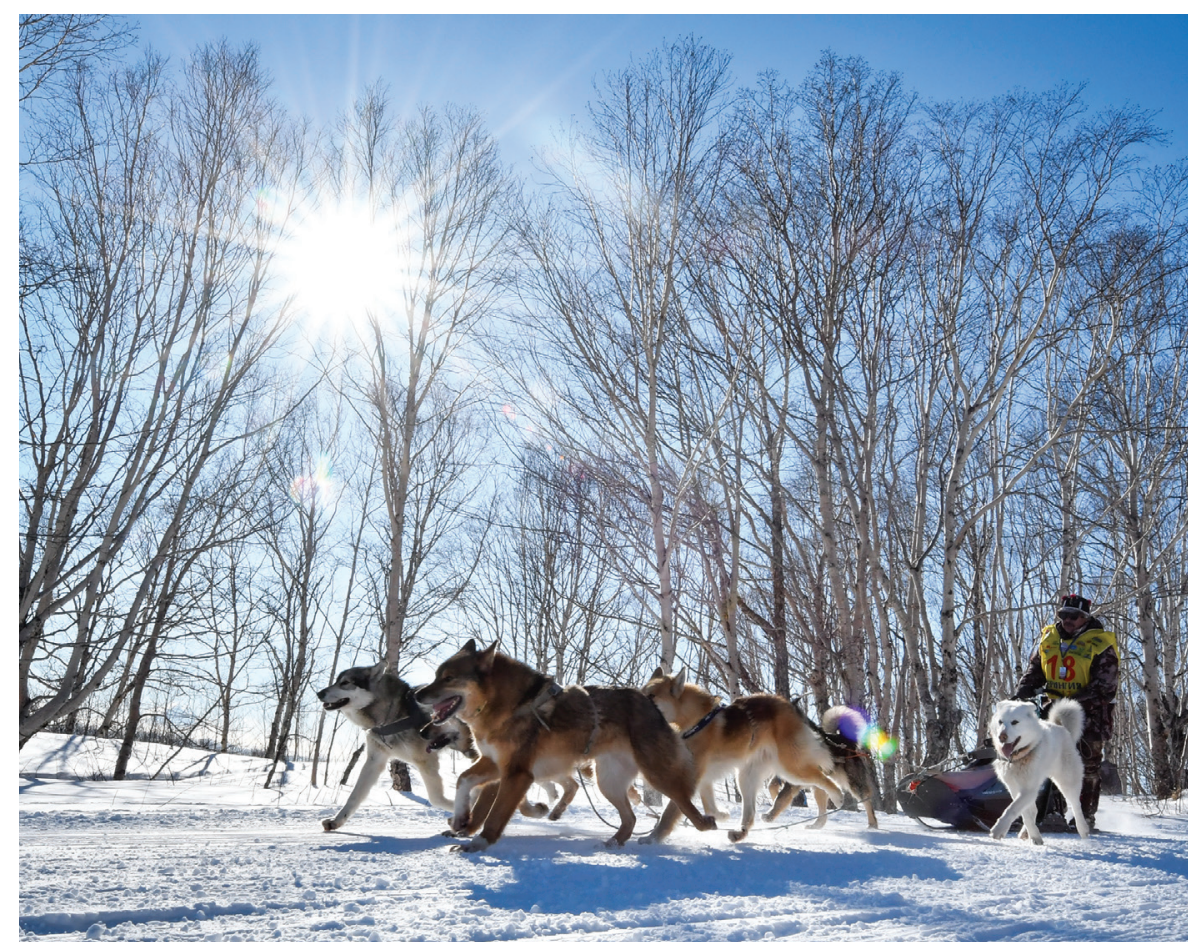

A participant in the 2017 Beringia dog-sledge race in Kamchatka, Russia.

extraordinary piece of history writing, seamlessly weaving together disparate elements. It is astonishingly rich in ethnographic detail, ecological precision, economic circumstance and historical texture. Most illuminating and original is Demuth's focus on the circulation of matter - in flesh, on hoof, inside fur and hide, and in buried minerals. The human ecology of energy transformations is a unifying element. With no opportunity for agriculture and little access to forest or grasslands, human life in Beringia was always an issue of stabilizing calories for people.

The whale, the ultimate assemblage of the solar energy first stored in plankton and krill, was the superior calorie converter and the preferred staple food of Beringians. But commercial whaling killed too many, too fast. Reindeer had also always sustained traditional communities, whose hunting practices kept populations viable. (This did not stop Alaska's first education commissioner, Sheldon Jackson, advocating that Beringians turn to caribou herding in the 1880 s. He declared that it would lift up what he called "a barbarian people" to "self-support and civilization".)

The foreigners arrived in waves from the 'lower 48' US states and central and western Russia. They disrupted the Beringians' finely balanced way of life, enrolling some in the extractive industries. On the US side, private ownership of land was introduced and mining claims generously distributed. The Soviet Union tried collectivization, which brought land and resources into common ownership. Collectivized whaling sat well with the traditional redistribution of harvests in Yupik villages, but these schemes, too, failed.
Both capitalist and communist approaches to complex resource flows focused on rapidly scaling up exploitation and increasing speed of returns. This 'fossil regime' did not work: the Beringian way, Demuth notes, "is to be very clear on the debts of the flesh". By tapping energy out of the region instead of reinvesting there, extraction fragmented communities.

Thus, for more than 100 years, starting with a nineteenth-century boom in whale oil, the hunt for resources turned to walruses, foxes, reindeer, gold and tin, then back to whales. It ended in stagnation. Current harvests of whales in Beringia are back to pre-commercial levels. Oil giant Shell drilled the floor of the Chukchi Sea in the early twenty-first century, but gave up in 2015, signalling a waning economic interest in the region. Booms are over, bust remains.

Meanwhile, the Arctic sea ice stabilizing the global climate is disappearing. Demuth recounts how a man of the Gwitchin people once told her that foreigners had brought the end of a world to his people with their missionaries, measles and decimation of species. But floating Beringia, he noted, no longer ends there: "now climate change will take the end of a world south".

Sverker Sörlin is a professor in the Division of History of Science, Technology and Environment at the KTH Royal Institute of Technology in Stockholm. With Paul Warde and Libby Robin, he is the author of The Environment: A History of the Idea. $\mathrm{He}$ leads the SPHERE programme, Study of the Planetary Human-Earth Relationship, funded by the European Research Council. e-mail:sverker.sorlin@abe.kth.se 